\title{
Hypertermic Intrathoracic Chemotherapy (HITHOC) for thymoma: a narrative review on indications and results
}

\author{
Vittorio Aprile ${ }^{1 \#}$, Diana Bacchin ${ }^{1 \#}$, Stylianos Korasidis ${ }^{1}$, Roberta Ricciardi ${ }^{2}$, Iacopo Petrini ${ }^{3}$, \\ Marcello Carlo Ambrogi ${ }^{1}$, Marco Lucchi ${ }^{1}$
}

${ }^{1}$ Thoracic Surgery, Cardiac Thoracic and Vascular Department, University of Pisa, Pisa, Italy; ${ }^{2}$ Department of Clinical and Experimental Medicine, Neurology Unit, University of Pisa, Pisa, Italy; ${ }^{3}$ Unit of Respiratory Medicine, Department of Critical Area and Surgical, Medical and Molecular Pathology, University Hospital of Pisa, Pisa, Italy

Contributions: (I) Conception and design: M Lucchi, V Aprile, D Bacchin; (II) Administrative support: M Lucchi, MC Ambrogi, S Korasidis; (III) Provision of study materials or patients: M Lucchi, MC Ambrogi, S Korasidis, R Ricciardi, I Petrini; (IV) Collection and assembly of data: V Aprile, D Bacchin; (V) Data analysis and interpretation: V Aprile, D Bacchin; (VI) Manuscript writing: All authors; (VII) Final approval of manuscript: All authors.

\#These authors contributed equally to this work.

Correspondence to: Vittorio Aprile. Division of Thoracic Surgery, Cardiac Thoracic and Vascular Department, University of Pisa, Pisa, Italy. Email: aprilevittorio@gmail.com.

Objective: With this narrative review, we retraced the history of hypertermic intrathoracic chemotherapy (HITHOC) since the beginning, analyzing literature on operative technique, feasibility and efficacy of this treatment. Moreover, we report the fifteen-year experience of our center in this relatively new technique, for what concerns both early postoperative results and long-term oncological outcomes.

Background: Thymomas are frequently misdiagnosed and recognized in advanced stage, often with pleural dissemination, especially when not associated to Myasthenia Gravis that allows an early diagnosis during the initial assessment. Moreover, the natural history of locally advanced thymoma is characterized by a high rate of pleural or pericardial relapses. Surgery has always been considered a milestone in thymoma's treatment, even in case of serous dissemination or relapses, although his role as exclusive therapy does not guarantee an acceptable local disease control. In case of disseminated disease, different multidisciplinary protocols have been experimented, from chemotherapy to radiation therapy, alone or associated to surgery, in order to increase overall and disease-free survival, but the breakthrough happened in the early 90s with the introduction of HITHOC following surgery. Combination of surgery and HITHOC resulted in less toxic than systemic chemotherapy and providing a good local disease control in patients with stage IVa thymomas or thymoma's pleural recurrences.

Methods: We searched PubMed for relevant literature, up to January 2020, on hypertermic intrapleural chemotherapy for thymomas (TPR or DNT), selecting only those reporting information about HITHOC protocol used, postoperative course and oncological outcomes.

Conclusions: HITHOC is a safe and feasible procedure, with a very low complication rate and negligible systemic effects of chemotherapeutic agents, effective in controlling both TPR and DNT, in particular as regards local disease-free survival.

Keywords: Hypertermic intrathoracic chemotherapy (HITHOC); thymoma; intracavitary chemotherapy; hyperthermia; redo-surgery

Submitted Sep 30, 2020. Accepted for publication Apr 27, 2021.

doi: 10.21037/atm-20-6704

View this article at: http://dx.doi.org/10.21037/atm-20-6704 


\section{Introduction}

\section{Pleural dissemination of thymoma}

Thymomas are tumors arising from the thymic epithelial cells involved in directing T-cells maturation and, although rare, represent more than half of the anterior mediastinal lesions (1). They are characterized, in most cases, by an indolent behavior consisting in a tendency to local invasion and spreading along the surroundings serous membranes rather than to lymph nodes or distant organs, that are detectable in less than $5 \%$ of cases (2). Surgical resection plays a fundamental role in the management of thymomas, not only for those diagnosed in early stage, but also in advanced stage ones, often as a part of multimodal strategy (3). More in details, for resectable advanced stage thymomas, surgery with radical intent followed by postoperative radiotherapy is highly recommended whereas adjuvant chemotherapy may be administered in cases of incomplete resection. On the other hand, those initially defined as unresectable, may benefit from trimodal therapy including upfront chemotherapy, followed by surgery and/ or radiotherapy, according to the level of downstaging achieved (4).

Pleural and pericardial implants may both be detected as initial presentation of stage IVa (according to Masaoka and TNM staging system), that accounts for less than $10 \%$ of all thymomas, or during the surveillance as recurrence in up to $30 \%$ of radically resected thymomas (5). In most cases, stage IVa lesions or recurrences, although spread only along the pleura, appear as multiple and diffuse droplet metastases and, consequently, surgery alone has been proven to be ineffective to achieve an efficient local control with a reported complete resection in less than twothirds of cases, even in case of extended resection such as pleuropneumonectomy (6-8).

Due to its low incidence, the literature regarding treatment of thoracic implants or recurrences is scarce and highly heterogenous, whereas different treatment protocols, combined or not with surgery, are proposed (9). In this scenario, development of the hyperthermic chemotherapy perfusion of chest cavity emerged as new procedure to improve the local control of disease and, more generally, the oncological outcomes. Our aim is to review the current literature on this topic, analyzing pros and cons of HITHOC usage in thymomatous patients.

We present the following article in accordance with the Narrative Review reporting checklist (available at http:// dx.doi.org/10.21037/atm-20-6704).

\section{HITHOC}

\section{Hypertermic intracavitary chemotherapy: an overview}

Local administration increases the efficacy of some chemotherapeutic agents by achieving high levels of drugs in the target tissues and, as consequence, reduces systemic toxicity. Since 1967 many authors reported the effects of moderate hyperthermia $\left(41-43{ }^{\circ} \mathrm{C}\right)$ both on in vitro and in vivo tumoral cells (10). These studies demonstrated that malignant cells have selected heat sensitivity mediated by various mechanisms such as nucleic acids and protein synthesis alterations, mitotic arrest, depression of aerobic tumor cells metabolism and an increased lysosomal activity that lead to cytoplasmatic damage. On these bases, in 1977 Overgaard speculated on the association between hyperthermia with irradiation and/or chemotherapy as an effective synergism against many types of cancer (11).

Hyperthermia increases the local effect of chemotherapeutic agents by enhancing penetration depth and cytotoxicity and by making endothelial cells of tumor vascularization more permeable. Moreover, this combination activates immune system response against tumor cells, through various mechanisms such as by activating heat shock proteins and releasing exosomes which stimulate natural killer and CD8+ T cells $(12,13)$.

Intracavitary thermochemotherapy following surgical resection was firstly applied to peritoneal carcinomatosis and then extended to the thoracic oncologic field: in those cases, in which surgery alone may not achieve microscopically complete resection, cytoreductive surgery combined with intracavitary chemotherapy has increasingly gained attention (14). Nowadays, HITHOC is a widespread treatment for pleural and abdominal carcinomatosis originating by various types of cancer, in order to allow a better local disease control and to avoid highly demolitive resections, with a low systemic effects rate due to minimal absorption of drugs by serous membranes (15).

\section{Indications of HITHOC}

In thoracic surgery field, HITHOC is performed since the 90 s, mostly in case of malignant pleural mesothelioma (MPM) and pleural spread of thymoma (stage IVa de novo thymoma, DNT, or pleural recurrences, TPR), even if its use for unilateral pleural carcinomatosis due to lung cancer or other primitive tumors as well as for rare pleural disease as the solitary fibrous tumor are also described by some authors (16-18). 
Selected patients affected by MPM may benefit from surgery followed by HITHOC especially in case of epithelioid or mixed histology and early stage according to IMIG classification (namely tumor confined to a hemithorax, that involves only the parietal pleura with or without involvement of the ipsilateral visceral pleura) (19). Despite the availability of several treatments for MPM, alone or combined (surgery, intrathoracic and systemic chemotherapy, radiation therapy, immunotherapy), survival rates are still underwhelming. In fact, due to a common late diagnosis, the impaired physical condition and the coexistence of multiple comorbidities, only few patients could be addressed to a multimodal treatment approach; whereas surgery alone is ineffective to achieve a complete resection, due to the laminar tumor growth within the entire pleura (20).

However, in a systematic review and meta-analysis of 2017, Zhao et al. showed how, in the setting of a multimodal treatment, HITHOC seems to prolong disease-free survival (DFS) and overall survival (OS) (21).

On the experience developed in MPM, HITHOC following a macroscopic complete resection has gained an increasingly wider consensus as part of a multimodal strategy also in case of intrathoracic stage IVa thymomas or unilateral TPR after primary tumor excision, with encouraging results such as longer local DFS and a lower re-recurrence rate (22). The main aim of this procedure is always to increase the local effect of surgery by killing potential residual tumoral cells and to avoid the common side effects of chemo or radiation therapy (23). The main indication is the presence of non-bulky resectable tumoral implants confined in a hemithorax in patients judged fit for surgery; although, several authors stated that HITHOC should be avoided in case of presence of intraoperative resection of the pericardium that could not be reconstructed by suturing or patching, intraoperative opening of the contralateral pleural space or major diaphragmatic reconstruction (for the risk of chemotherapeutic agents leaking), large decortications, that could affect drugs absorption, and, lastly, in case of severe impairment of hepatic, cardiac or renal function (24).

\section{Perfusion technique}

In most cases, surgery and HITHOC are planned in a multidisciplinary setting usually including oncologists, surgeons, anesthesiologists, radiotherapists, and neurologists in presence of Myasthenia Gravis. Respiratory and cardiologic evaluation is then performed, to establish patients' suitability, while peri-operative intravenous hydration and corticosteroids are eventually administered, according to each Center protocols, to minimize HITHOC early side effects (24).

HITHOC is performed mostly intraoperatively under general anesthesia after the surgical procedure, even if Liu et al. in 2016 described their experience on bedside application that could be repeated in the same patient, with a very low morbidity rate (2\%) (25). Perfusion is generally started after surgical treatment, ranging from the resection of the single implants to partial pleurectomy $(\mathrm{PP})$, pleurectomy/decortication (P/D), even to extrapleural pneumonectomy (EPP) (23). Surgical approach is usually based on patient's status and tumor histology and extension. A perfusion dedicated system is connected to the patient through the pleural drains and, after starting circulating, perfusion saline isotonic solution is heated up to the target temperature (in literature is described a set point between 40 and $45^{\circ} \mathrm{C}$ ). Then, chemotherapeutic drugs are injected into the circuit by the inflow catheter, let circulate for about 60 to 120 minutes and subsequently washed out from the outflow catheter by reversing the circuit flow (24-28).

\section{Chemotherapy regimens used}

Many authors described their experience with intracavitary hyperthermic chemotherapy (Table 1), but still there is no consensus about the most appropriate chemotherapeutic regimen. However, the drugs of choice are generally Cisplatin, Anthracyclines and Mitomycin, due to their direct cytotoxic activity.

Cisplatin is the most HITHOC used drug, at a mean dosage of $100 \mathrm{mg} / \mathrm{m}^{2}$ in accordance with the single Center protocol and the eventual association with other agents.

Rusch et al. presented in 1992 a prospective phase II trial about treatment with normothermic perfusion of Cisplatin $\left(100 \mathrm{mg} / \mathrm{m}^{2}\right)$ and Mytomicin $\left(8 \mathrm{mg} / \mathrm{m}^{2}\right)$ in 12 MPM patients. They found out that both drugs reached higher concentration in the pleural fluid than plasma (from 3- to 5-times higher on a logarithmic scale), even if drugs' half-lives were significantly longer in plasma than pleural fluid. This last finding supports the need to adopt the same precautions of intravenous chemotherapy administration (e.g., pre-hydration) to minimize the risk of nephrotoxicity (29).

Ratto and colleagues in 1999 published a study on feasibility and pharmacokinetic in 10 MPM patients 
Table 1 Various HITHOC protocols used for patients affected by TPR or DNT

\begin{tabular}{|c|c|c|c|c|}
\hline Author (year) & Drugs (dosage $\mathrm{mg} / \mathrm{m}^{2}$ ) & Target temperature $\left({ }^{\circ} \mathrm{C}\right)$ & Perfusion time (minutes) & Number of pleural catheters \\
\hline Refaely (2001) & Cisplatin [100-200] & $40.3-45$ & 60 & 2 (1 inflow, 1 outflow) \\
\hline de Bree (2002) & $\begin{array}{l}\text { Cisplatin [50-80]; } \\
\text { Doxorubicin [15-25] }\end{array}$ & $40-41$ & 90 & 4 (1 inflow, 3 outflow) \\
\hline Ried (2013) & Cisplatin [100-150] ${ }^{*}$ & 42 & 60 & $\begin{array}{l}3-5 \text { (1-2 inflow, } \\
2-3 \text { outflow) }\end{array}$ \\
\hline Yellin (2013) & $\begin{array}{l}\text { Cisplatin }[100] \\
\text { Doxorubicin }[50-60]^{\star *}\end{array}$ & 45 & 60 & 2 (1 inflow, 1 outflow) \\
\hline Yu (2013) & Cisplatin [100] & $42-43$ & 120 & 2 (1 inflow, 1 outflow) \\
\hline Ried (2014) & Cisplatin [100-150] & 42 & 60 & $\begin{array}{l}3-5 \text { (1-2 inflow, } \\
2-3 \text { outflow) }\end{array}$ \\
\hline Aprile (2020) & $\begin{array}{l}\text { Cisplatin [80]; } \\
\text { Epirubicin [25] }\end{array}$ & 42 & 60 & 2 (1 inflow, 1 outflow) \\
\hline
\end{tabular}

${ }^{*} 150 \mathrm{mg} / \mathrm{m}^{2}$ used only in the last two procedures; ${ }^{* *}$ used since 2002 . HITHOC, hypertermic intrathoracic chemotherapy; TPR, pleural recurrences; DNT, de novo thymoma.

treated with surgery associated to hyper- or normothermic Cisplatin perfusion. They found out that the local tissue/ perfusate ratio of platinum concentrations tended to be higher after hyperthermic perfusion rather than normothermic perfusion. Like other authors before, they also noticed a platinum concentration in the pleural space 3to 5-times higher than the plasmatic one and no platinumrelated toxicity was observed (30).

In 2013, Ried et al. compared two groups of patients affected by MPM or stage IVa thymoma, who received HITHOC with Cisplatin $100 \mathrm{mg} / \mathrm{m}^{2}$ ( $1^{\text {st }}$ group, 5 patients) and $150 \mathrm{mg} / \mathrm{m}^{2}$ ( $2^{\text {nd }}$ group, 5 patients), finding out that increasing the baseline dosage was not associated to elevation of serum platinum concentration, even if three patients exposed to the higher dosage reported nephrotoxicity. The mean peak of cisplatin in the serum was reached after 60 minutes of HITHOC. They encountered also lower platinum concentrations in patients underwent pneumonectomy rather than pleurectomy/decortication; this fact may indicate that lung parenchyma has a great role in drugs absorption (15).

Doxorubicin, instead, is a pharmacokinetically advantageous drug for intraperitoneal administration, due of its high molecular weight together with hydrophilic properties, that allows a slow peritoneal clearance acting at higher concentration on tumor cells implanted in the peritoneal cavity (31).

In 1998 a mice model set by Jacquet et al. showed that, after intraperitoneal administration of Doxorubicin at 37 and $43{ }^{\circ} \mathrm{C}$, there were no differences between drug plasmatic concentrations in the two groups but, in the hyperthermia group, Doxorubicin and its metabolites reached a greater tissue distribution in some abdominal organs frequently interested by metastases such as omentum, spleen, liver (32).

Van Ruth and colleagues performed in 4 years (1998-2001) 24 HITHOC for MPM using Cisplatin $\left(80 \mathrm{mg} / \mathrm{m}^{2}\right)$ and Doxorubicin $\left(15-35 \mathrm{mg} / \mathrm{m}^{2}\right)$ for 90 minutes of perfusion at $41{ }^{\circ} \mathrm{C}$. They focused their attention mostly on Doxorubicin pharmacokinetics, finding out high local concentrations with minimal systemic uptake; for what concerns Cisplatin concentrations in plasma and pleural fluid, they confirmed previous studies' results. Regarding chemotherapy side-effects, they encountered only one case of transient platinum-related nephrotoxicity probably related to inadequate perioperative hydration (33).

Mitomycin is scarcely used in these settings; Sugarbaker et al. analyzed pharmacokinetics of this $\operatorname{drug}\left(15 \mathrm{mg} / \mathrm{m}^{2}\right)$ in combination with Doxorubicin $\left(15 \mathrm{mg} / \mathrm{m}^{2}\right)$ in three groups of patients underwent intraperitoneal, thoracoabdominal and intrathoracic hypertermic chemiotherapy perfusion (HIPEC; HITAC and HITHOC, respectively) for various types of cancer. In this regard, major finding was the lower 
absorption of drugs in the HITHOC group; this led the authors to speculate that the same dosages used for HIPEC should be administered safely also in HITHOC (34).

\section{Methods}

Relevant literature up to January 2020 was searched in PubMed using as keywords: "hyperthermic intrapleural chemotherapy," "intrapleural hyperthermic," or "hyperthermic intrathoracic chemotherapy," or "HIPEC" and "thymoma," or "HITHOC". The search was limited to English language and relevant studies were identified, screened and reviewed by all the authors.

We conducted an accurate research of all studies focused on the outcomes of HITHOC in TPR or DNT published in the last two decades, and we selected only those with information about HITHOC protocol proposed and information on postoperative course as well as oncological outcomes (Table 2). Unpublished material, congress abstracts, and proceedings were not considered.

\section{Results}

In 2001, Yellin and colleagues published their experience on HITHOC in 27 patients affected by various tumors (of whom, 7 with DNT). They used Cisplatin beginning with a minimum dosage of $60 \mathrm{mg} / \mathrm{m}^{2}$ up to $200 \mathrm{mg} / \mathrm{m}^{2}$ at about $41{ }^{\circ} \mathrm{C}$ for 1 hour. There was no technical problem or hemodynamic instability during the perfusion. Regarding HITHOC toxicity, only one patient developed thrombocytopenia; there were described also nausea and non-infectious fever. After a mean followup of 60.2 months, 5 thymoma patients were alive without disease, one patient died for thymoma's systemic progression and another one died because of leukemia. The authors concluded that surgery associated to HITHOC may improve OS and DFS in patients affected by advanced stage thymoma (26).

In the same year, Refaely et al. investigated the role of HITHOC in 15 patients affected by stage IVa thymoma (10 patients) or thymic carcinoma (5 patients). Surgical resection was radical in 7 DNT patients, while 3 patients had positive resection margins (1 R1 and $2 \mathrm{R} 2$ ). HITHOC protocol provided Cisplatin at a dosage between 100 and $200 \mathrm{mg} / \mathrm{m}^{2}$ at about $43{ }^{\circ} \mathrm{C}$ for 1 hour. The procedure was devoid of complications and the authors did not report any platinum-related toxicity. Cumulative survival rates for thymoma patients were $90 \%$ at 3 years from surgery (one patient died within this period for disease progression) and $70 \%$ at 5 years. In conclusion, the author hypothesized that macroscopic complete resection of primitive thymoma and of all pleural implants followed by intraoperative HITHOC may improve OS and local disease control (35).

de Bree et al. in 2002 treated 14 patients ( 3 for TPR an 11 for early-stage MPM) with HITHOC, using a combination of Doxorubicin $\left(15\right.$ to $\left.25 \mathrm{mg} / \mathrm{m}^{2}\right)$ and Cisplatin $\left(80 \mathrm{mg} / \mathrm{m}^{2}\right)$ at $40-41{ }^{\circ} \mathrm{C}$ for 90 minutes. In one case, TPR resection margins were $\mathrm{R} 1$ and the patient was then treated with adjuvant radiotherapy. Another patient presented a contralateral recurrence after 13 months, treated with surgery and HITHOC again. OS after a mean follow-up of 18 months was $100 \%$. One patient presented nephrotoxicity as platinum-related side-effect. To sum up, the Dutch group postulated that HITHOC was feasible in patients with pleural metastases of thymoma and early-stage MPM, and associated with an acceptable morbidity rate, and it might provide an improved locoregional disease control (27).

In a 2013 study, Ried and colleagues reported their early experience on 16 patients (8 with stage IVa DNT, 8 with MPM). Thymoma's patients were operated on in two times (firstly by median sternotomy to resect primary tumor, then by thoracotomy to remove pleural metastasis). $\mathrm{P} / \mathrm{D}$ was performed in all cases, with the intent to achieve a macroscopically complete resection of the tumor, followed by intraoperative HITHOC with Cisplatin $\left(100 \mathrm{mg} / \mathrm{m}^{2}\right.$ for $60^{\prime}$ at $42^{\circ} \mathrm{C}$ ). Four thymoma's patients already underwent neoadjuvant chemotherapy (CT) and three of them also received adjuvant chemotherapy. Adjuvant CT was administered also in other three patients that did not receive any induction treatment. All procedures were completed without any complication, even though severe postoperative morbidity occurred in two patients (pneumonia and sepsis, treated with pneumonectomy, and axillary and subclavian venous thrombosis). The authors examined oncological outcomes and, for what concerns DNT patients, found out that one patient presented mediastinal relapse of thymoma after 13 months from surgery (12.5\%) and another one died of disease after 35 months (12.5\%); both patients received neoadjuvant and adjuvant CT. All other patients were alive without disease after a mean follow-up of 22 months (36). A year later, always Ried et al. published their updated experience on stage III and IVa thymomas (respectively, 9 and 13 patients). In the latter group, 9 patients underwent postoperative HITHOC and only one patient died after 28 months for locoregional disease recurrence while in one case thymoma relapsed after 6 months from neoadjuvant 
Table 2 Surgical resections, postoperative course, and oncological outcomes in various authors' experience

\begin{tabular}{|c|c|c|c|c|c|c|c|}
\hline Author (year) & Nr. of patients & DNT/ TPR & $\begin{array}{l}\text { Surgery } \\
\text { performed + } \\
\text { HITHOC }\end{array}$ & $\begin{array}{l}\text { Perioperative } \\
\text { morbidity (\%) }\end{array}$ & $\begin{array}{l}\text { Perioperative } \\
\text { mortality }\end{array}$ & $\begin{array}{l}\text { Follow-up, } \\
\text { survival rates } \\
\text { and oncological } \\
\text { outcomes }\end{array}$ & $\begin{array}{l}\text { HITHOC-related } \\
\text { side-effects (\%) }\end{array}$ \\
\hline \multirow[t]{3}{*}{ Yellin (2001) } & 7 & DNT & $1 \mathrm{EPP}$ & -1 bleeding (14.3) & 0 & $\begin{array}{l}\text { Mean follow-up: } \\
60.2 \text { months }\end{array}$ & $\begin{array}{l}1 \\
\text { thrombocytopenia } \\
(14.3)\end{array}$ \\
\hline & & & $3 \mathrm{PP}$ & & & $\begin{array}{l}1 \text { DOD after } \\
7 \text { months (14.3) }\end{array}$ & $\begin{array}{l}1 \text { non-infectious } \\
\text { fever (14.3) }\end{array}$ \\
\hline & & & $1 \mathrm{PP}+$ wedge & & & $\begin{array}{l}1 \text { DOC after } \\
36 \text { months (14.3) }\end{array}$ & \\
\hline \multirow{3}{*}{ Refaely (2001) } & & & $1 \mathrm{EPP}$ & $\begin{array}{l}\text {-1 diaphragmatic } \\
\text { paralysis* }(10.0)\end{array}$ & & 5-year OS: 70\% & $\begin{array}{l}2 \text { non-infectious } \\
\text { fever }(20.0)\end{array}$ \\
\hline & & & & $\begin{array}{l}-1 \text { wound } \\
\text { infection }^{\star \star}(10.0)\end{array}$ & & & \\
\hline & & & & -1 bleeding (10.0) & & & \\
\hline \multirow[t]{3}{*}{ De Bree (2002) } & 3 & TPR & $2 \mathrm{P} / \mathrm{D}$ & $\begin{array}{l}1 \text { wound } \\
\text { dehiscence (33.3) }\end{array}$ & 0 & $\begin{array}{l}\text { Mean follow-up: } \\
18 \text { months }\end{array}$ & $\begin{array}{l}1 \text { nephrotoxicity } \\
(33.3)\end{array}$ \\
\hline & & & $1 \mathrm{EPP}$ & & & OS: $100 \%$ & \\
\hline & & & & & & $\begin{array}{l}1 \text { contralateral } \\
\text { recurrence at } \\
13 \text { months (33.3) }\end{array}$ & \\
\hline \multirow{2}{*}{ Ried (2013) } & & & & $\begin{array}{l}-1 \text { subclavian } \\
\text { and axillary veins } \\
\text { thrombosis (12.5) }\end{array}$ & & $\begin{array}{l}\text { DFS: } 87.5 \%(1 \\
\text { relapse after } \\
13 \text { months) }\end{array}$ & \\
\hline & & & & & & $\begin{array}{l}\text { OS: } 87.5 \% \text { (1 } \\
\text { DOD after } \\
35 \text { months) }\end{array}$ & \\
\hline
\end{tabular}

Table 2 (continued) 
Table 2 (continued)

\begin{tabular}{|c|c|c|c|c|c|c|c|}
\hline Author (year) & Nr. of patients & DNT/ TPR & $\begin{array}{l}\text { Surgery } \\
\text { performed + } \\
\text { HITHOC }\end{array}$ & $\begin{array}{l}\text { Perioperative } \\
\text { morbidity (\%) }\end{array}$ & $\begin{array}{l}\text { Perioperative } \\
\text { mortality }\end{array}$ & $\begin{array}{l}\text { Follow-up, } \\
\text { survival rates } \\
\text { and oncological } \\
\text { outcomes }\end{array}$ & $\begin{array}{l}\text { HITHOC-related } \\
\text { side-effects (\%) }\end{array}$ \\
\hline \multirow[t]{8}{*}{ Yellin (2013) } & 14 & TPR & $\mathrm{P} / \mathrm{D}$ & -Prolonged air leak & 0 at 30 days & $\begin{array}{l}\text { Mean follow-up: } \\
62 \text { months }\end{array}$ & \multirow[t]{8}{*}{ Nausea } \\
\hline & & & \multirow[t]{7}{*}{$\mathrm{PP} \pm$ wedge } & -Pneumonia & & 10-year OS: 56\% & \\
\hline & & & & \multicolumn{2}{|l|}{-Myasthenic crisis } & $\begin{array}{l}\text { Mean OS: } \\
140 \text { months }\end{array}$ & \\
\hline & & & & \multicolumn{2}{|l|}{-Respiratory failure } & 5 -year DFS $=48 \%$ & \\
\hline & & & & \multirow{4}{*}{ (Total 28.6) } & & 10-year OS: 73\% & \\
\hline & & & & & & $\begin{array}{l}\text { Mean OS: } \\
184 \text { months }\end{array}$ & \\
\hline & & & & & & 5 -year DFS $=61 \%$ & \\
\hline & & & & & & $\begin{array}{l}10-\text { year DFS } \\
=43 \%\end{array}$ & \\
\hline Yu (2013) & 4 & 2 DNT & CRS & 1 pneumonia $(25.0)$ & 0 & $\begin{array}{l}\text { Follow-up: } \\
\text { 1-4 years }\end{array}$ & $\begin{array}{l}2 \text { intraoperative } \\
\text { sinus tachycardia } \\
(50.0)\end{array}$ \\
\hline \multirow{4}{*}{ Ried (2014) } & & & & \multirow[t]{4}{*}{$\begin{array}{l}-1 \text { subclavian } \\
\text { and axillary veins } \\
\text { thrombosis (11.1) }\end{array}$} & & DFI: 30.2 months & \\
\hline & & & & & & DFS: $89 \%$ & \\
\hline & & & & & & $\begin{array}{l}\text { Recurrence rate: } \\
22.7 \%\end{array}$ & \\
\hline & & & & & & $\begin{array}{l}\text { Median OS: } \\
25 \text { months }\end{array}$ & \\
\hline
\end{tabular}

Table 2 (continued) 
Table 2 (continued)

\begin{tabular}{|c|c|c|c|c|c|c|c|}
\hline Author (year) & Nr. of patients & DNT/ TPR & $\begin{array}{l}\text { Surgery } \\
\text { performed + } \\
\text { HITHOC }\end{array}$ & $\begin{array}{l}\text { Perioperative } \\
\text { morbidity (\%) }\end{array}$ & $\begin{array}{l}\text { Perioperative } \\
\text { mortality }\end{array}$ & $\begin{array}{l}\text { Follow-up, } \\
\text { survival rates } \\
\text { and oncological } \\
\text { outcomes }\end{array}$ & $\begin{array}{l}\text { HITHOC-related } \\
\text { side-effects (\%) }\end{array}$ \\
\hline \multirow[t]{4}{*}{ Maury (2017) } & 19 & TPR & $4 \mathrm{PP}$ & -1 pyothorax (5.3) & 0 & $\begin{array}{l}\text { Median follow-up: } \\
39 \text { months }\end{array}$ & $\begin{array}{l}1 \text { bone marrow } \\
\text { aplasia (5.3) }\end{array}$ \\
\hline & & & $1 \mathrm{EPP}$ & -1 pneumonia (5.3) & & $\begin{array}{l}\text { Median OS: } \\
63 \text { months }\end{array}$ & $\begin{array}{l}2 \text { acute reversible } \\
\text { kidney failure (10.6) }\end{array}$ \\
\hline & & & $14 \mathrm{PP}+$ wedge & $\begin{array}{l}-1 \text { cardiac } \\
\text { arrythmia }(5.3 \%)\end{array}$ & & $\begin{array}{l}\text { Median DFS: } \\
53 \text { months }\end{array}$ & \\
\hline & & & & & & $\begin{array}{l}\text { Median local DFS: } \\
41 \text { months }\end{array}$ & \\
\hline \multirow{3}{*}{ Aprile (2020) } & & & & $\begin{array}{l}\text {-1 hydro- } \\
\text { pneumothorax } \\
\text { +bleeding (3.7) }\end{array}$ & & 10-year OS: $77 \%$ & \\
\hline & & & & $\begin{array}{l}-2 \text { prolonged air } \\
\text { leaks }(7.4)\end{array}$ & & $\begin{array}{l}\text { Mean OS: } \\
153.1 \text { months }\end{array}$ & \\
\hline & & & & $\begin{array}{l}-1 \text { prolonged air } \\
\text { leak + bleeding } \\
(3.7)\end{array}$ & & $\begin{array}{l}2^{\text {nd }} \text { recurrence } \\
\text { rate: } 44.4 \%\end{array}$ & \\
\hline
\end{tabular}

*3 months after surgery; ${ }^{\star \star} 1$ month after surgery; ${ }^{\star \star \star}$ patient already undergone adjuvant chemotherapy. DNT, de novo stage IVa thymoma; TPR, thymoma pleural recurrence; EPP, extrapleural pneumonectomy; PP, partial pleurectomy; P/D, pleurectomy/decortication; CRS, cytoreductive surgery; OS, overall survival; DFS, disease-free survival; DFI, disease-free interval; DOD, dead of disease; DOC, dead of other causes; NR, not reported.

CT, surgery and HITHOC, and was successfully treated with $2^{\text {nd }}$ line CT. At the end of the study, $89 \%$ of the patients were alive without disease and the median survival resulted 25 months. In conclusion the authors argued that, in advanced stage thymomas, surgery with radical intention should be considered part of a multimodal treatment comprehensive of induction CT, RT in cases of R1/R2 resections and HITHOC for pleural seeding to achieve a better local disease control (37).

In a pleural perfusion study for various thymic malignancies (stage IVa thymoma, TPR and thymic carcinoma), Yellin et al. used Cisplatin $\left(100 \mathrm{mg} / \mathrm{m}^{2}\right)$ and, since 2002, also Doxorubicin (50-60 mg/m²). They operated on 35 patients (14 TPR, 17 DNT and 4 thymic carcinomas) without any peri-procedural complication and, after a mean follow-up of 62 months, authors concluded that cytoreductive surgery and HITHOC is associated to excellent oncological results with a longer OS and DFS in DNT compared to TPR patients, as well as demolitive surgery as pleuropneumonectomy should be avoided in 
favor of lung-preserving resections, due to high morbidity and mortality rate (38).

Even in 2013, Yu and colleagues published a study on 4 patients subjected to video-assisted cytoreductive surgery and HITHOC (Cisplatin $100 \mathrm{mg} / \mathrm{m}^{2}$ for 2 hours) for TPR (2 patients) and stage IVa DNT (2 patients). They were followed-up for 1 to 4 years and only one patient died after 12 months for heart failure, the other three patients were alive without disease. During the procedure, the authors observed only two cases of tachycardia as hyperthermiarelated side effect (39).

Maury et al. in their 2017 paper operated on 19 patients for TPR; their HITHOC regimen consisted in Cisplatin $\left(50 \mathrm{mg} / \mathrm{m}^{2}\right)$ and Mitomycin $\left(25 \mathrm{mg} / \mathrm{m}^{2}\right)$ and perfusion lasted 60 minutes at about $42{ }^{\circ} \mathrm{C}$. The authors reported three cases of HITHOC-related side effects ( 1 bone marrow aplasia and 2 acute reversible kidney failure) and three major postoperative complications ( 1 pyothorax, 1 cardiac arrythmia and 1 pneumonia). For what concerns oncological outcomes, after a median follow-up period of 39 months, 14 patients were alive, 12 of them with no evidence of disease. Only one patient died for thymomarelated causes. Seven patients $(37 \%)$ presented tumor recurrence with a median disease-free survival of 53 months, while the median local disease-free interval was 41 months. Median OS was 63 months and 1- and 5-year survival rates were $93 \%$ and $86 \%$, respectively. In conclusion, the authors agreed with other previous studies that HITHOC is a safe and feasible procedure, effective in prolonging disease-free survival in patients with relapsing thymoma if associated to cytoreductive lung-sparing surgery with radical intent. They also highlighted the necessity of larger studies to assess what chemotherapy regimen is more effective in this setting and the role of adjuvant chemotherapy in TPR (28).

Our group recently published twelve-year experience on TPR treatment. The study retrospectively collected data on 40 patients affected by relapsing thymoma; 27 of them received postoperative HITHOC (Cisplatin $80 \mathrm{mg} / \mathrm{m}^{2}$ and Epirubicin $25 \mathrm{mg} / \mathrm{m}^{2}$ at $42{ }^{\circ} \mathrm{C}$ for 1 hour) while 13 patients, in which HITHOC was contraindicated, underwent only cytoreductive surgery. Presently, this is the only study that compares surgery+HITHOC and surgery alone results. The two groups presented similar postoperative morbidity and no procedure-related mortality. Cumulative survival rates were also similar in the two groups (140.3 months in the surgery group, 153.1 months in the surgery + HITHOC group, P: 0.139), but they significantly differed in terms of local disease-free interval (57 months for the first group,
88 months for the second one, P: 0.046). Moreover, at multivariable analysis the only two factors affecting diseasefree survival were adjuvant therapy after primitive tumor excision and HITHOC administration (P: 0.028 and 0.021, respectively). On the other hand, OS was affected only by radicality of redo-surgery. In the light of these data, we can confirm previous studies' findings on HITHOC safety and effectiveness, thanks overall to the comparative approach adopted. Moreover, surgical radicality's role is also confirmed, even if we noticed that sparing lung, pericardium and diaphragm, even at the cost of a non-radical resection, allows to avoid thymoma's cells spread leaving the patients in good conditions to be addressed to further treatments (24).

\section{Conclusions}

The cornerstone of thymoma surgical treatment is complete resection, that has proven to be the most important prognostic factor, although thymomas have high chemo- and radio-sensitive (40). In case of stage IVa tumors or recurrences occurring with pleural, pericardial or diaphragmatic implants, achieving a complete resection is unrealistic because of high probability of minimal residue, or extremely debilitating when the cost of the radicality is an extended and demolitive operation such as EPP. To reduce perioperative morbidity and mortality, lung, pericardial and diaphragmatic-sparing pleurectomy/decortication has been introduced with promising results despite the risk of potential R1 or minimal R2 resection. In this scenario, HITHOC perfusion following macroscopic radical pleural tumor resection has been developed to improve local tumor control and reduce the recurrence rate.

In our fifteen-years' experience with HITHOC in thymomatous patients, we settled as standard dosage $80 \mathrm{mg} / \mathrm{m}^{2}$ for Cisplatin and $25 \mathrm{mg} / \mathrm{m}^{2}$ for Epirubicin, with no evidence of HITHOC-related side-effects and good local disease control. In different reports, higher dosages seemed to be associated to similar oncological results but also with some episodes of severe chemo-related toxicity. This may suggest that increasing chemotherapy dosages is feasible but, actually, not strictly recommended, even if precise dose-dependent effects are still far to be assessed. Time of perfusion and number of pleural drainage catheters seem not to be determinants in early and long-term outcomes. Sixty minutes is the minimum described perfusion time and, in our opinion, is a good balance between oncological treatment and time under general anesthesia. We believe 
that at least two pleural drainages (apical and basal) should be placed to adequately perform the complete irrigation of the whole pleural space. More than two drainages should be evaluated for each case on the base of the complexity and the extent of the intervention.

By the way, unfortunately, prospective and randomized studies to determine which is the best operative technique and the real oncological effectiveness of HITHOC are still lacking due to low incidence of cases suitable for this procedure and, to date, all the evidence is confined to retrospective studies with few patients and different protocols described. Therefore, more structured studies are needed to refine this technique as well as an international multicentric effort in involving a larger number of patients would be worthwhile. However, all the authors who experimented this technique, agreed on the safety and feasibility of the procedure with a very low complication rate and negligible systemic effects of chemotherapeutic agents, as well as they support the effectiveness of postresection HITHOC in controlling both TPR and DNT, in particular as regards local disease-free survival.

\section{Acknowledgments}

Funding: None.

\section{Footnote}

Provenance and Peer Review: This article was commissioned by the Guest Editor (Marcello Migliore) for the series "Hyperthermic Intraoperative Chemotherapy (HITHOC) in thoracic surgical oncology" published in Annals of Translational Medicine. The article has undergone external peer review.

Reporting Checklist: The authors have completed the Narrative Review reporting checklist. Available at http:// dx.doi.org/10.21037/atm-20-6704

Conflicts of Interest: All authors have completed the ICMJE uniform disclosure form (available at http://dx.doi. org/10.21037/atm-20-6704). The series "Hyperthermic Intraoperative Chemotherapy (HITHOC) in thoracic surgical oncology" was commissioned by the editorial office without any funding or sponsorship. The authors have no other conflicts of interest to declare.
Ethical Statement: The authors are accountable for all aspects of the work in ensuring that questions related to the accuracy or integrity of any part of the work are appropriately investigated and resolved.

Open Access Statement: This is an Open Access article distributed in accordance with the Creative Commons Attribution-NonCommercial-NoDerivs 4.0 International License (CC BY-NC-ND 4.0), which permits the noncommercial replication and distribution of the article with the strict proviso that no changes or edits are made and the original work is properly cited (including links to both the formal publication through the relevant DOI and the license). See: https://creativecommons.org/licenses/by-nc-nd/4.0/.

\section{References}

1. Müller-Hermelink HK, Marino M, Palestro G, et al. Immunohistological evidences of cortical and medullary differentiation in thymoma. Virchows Arch A Pathol Anat Histopathol 1985;408:143-61.

2. Kondo K, Monden Y. Lymphogenous and hematogenous metastasis of thymic epithelial tumors. Ann Thorac Surg 2003;76:1859-64; discussion 1864-5.

3. Davenport E, Malthaner RA. The role of surgery in the management of thymoma: a systematic review. Ann Thorac Surg 2008;86:673-84.

4. Girard N, Mornex F, Van Houtte P, et al. Thymoma: a focus on current therapeutic management. J Thorac Oncol 2009;4:119-26.

5. Scorsetti M, Leo F, Trama A, et al. Thymoma and thymic carcinomas. Crit Rev Oncol Hematol 2016;99:332-50.

6. Huang J, Rizk NP, Travis WD, et al. Feasibility of multimodality therapy including extended resections in stage IVA thymoma. J Thorac Cardiovasc Surg 2007;134:1477-83.

7. Chiappetta M, Zanfrini E, Giraldi L, et al. Prognostic factors after treatment for iterative thymoma recurrences: A multicentric experience. Lung Cancer 2019;138:27-34.

8. Venuta F, Anile M, Diso D, et al. Thymoma and thymic carcinoma. Eur J Cardiothorac Surg 2010;37:13-25.

9. Ströbel P, Bauer A, Puppe B, et al. Tumor recurrence and survival in patients treated for thymomas and thymic squamous cell carcinomas: a retrospective analysis. J Clin Oncol 2004;22:1501-9.

10. Cavaliere R, Ciocatto EC, Giovanella BC, et al. Selective 
heat sensitivity of cancer cells. Biochemical and clinical studies. Cancer 1967;20:1351-81.

11. Overgaard J. Effect of hyperthermia on malignant cells in vivo. A review and a hypothesis. Cancer 1977;39:2637-46.

12. Matsuzaki Y, Tomita M, Shimizu T, et al. Induction of apoptosis by intrapleural perfusion hyperthermochemotherapy for malignant pleural mesothelioma. Ann Thorac Cardiovasc Surg 2008;14:161-5.

13. Toraya-Brown S, Fiering S. Local tumour hyperthermia as immunotherapy for metastatic cancer. Int J Hyperthermia 2014;30:531-9.

14. van Ruth S, Baas P, Haas RL, et al. Cytoreductive surgery combined with intraoperative hyperthermic intrathoracic chemotherapy for stage I malignant pleural mesothelioma. Ann Surg Oncol 2003;10:176-82.

15. Ried M, Potzger T, Braune N, et al. Local and systemic exposure of cisplatin during hyperthermic intrathoracic chemotherapy perfusion after pleurectomy and decortication for treatment of pleural malignancies. J Surg Oncol 2013;107:735-40.

16. Migliore M, Nardini M. Does cytoreduction surgery and hyperthermic intrathoracic chemotherapy prolong survival in patients with N0-N1 nonsmall cell lung cancer and malignant pleural effusion? Eur Respir Rev 2019;28:190018.

17. Sakaguchi H, Ishida H, Nitanda H, et al. Pharmacokinetic evaluation of intrapleural perfusion with hyperthermic chemotherapy using cisplatin in patients with malignant pleural effusion. Lung Cancer 2017;104:70-4.

18. Patel MD, Damodaran D, Rangole A, et al. Hyperthermic Intrathoracic Chemotherapy (HITHOC) for Pleural Malignancies-Experience from Indian Centers. Indian J Surg Oncol 2019;10:91-8.

19. Rusch VW. A proposed new international TNM staging system for malignant pleural mesothelioma. From the International Mesothelioma Interest Group. Chest 1995;108:1122-8.

20. Bertoglio P, Aprile V, Ambrogi MC, et al. The role of intracavitary therapies in the treatment of malignant pleural mesothelioma. J Thorac Dis 2018;10:S293-7.

21. Zhao ZY, Zhao SS, Ren M, et al. Effect of hyperthermic intrathoracic chemotherapy on the malignant pleural mesothelioma: a systematic review and meta-analysis. Oncotarget 2017;8:100640-7.

22. Ambrogi MC, Korasidis S, Lucchi M, et al. Pleural recurrence of thymoma: surgical resection followed by hyperthermic intrathoracic perfusion chemotherapy $\dagger$. Eur J Cardiothorac Surg 2016;49:321-6.
23. Ried M, Marx A, Götz A, et al. State of the art: diagnostic tools and innovative therapies for treatment of advanced thymoma and thymic carcinoma. Eur J Cardiothorac Surg 2016;49:1545-52.

24. Aprile V, Bacchin D, Korasidis S, et al. Surgical treatment of pleural recurrence of thymoma: is hyperthermic intrathoracic chemotherapy worthwhile? Interact Cardiovasc Thorac Surg 2020;30:765-72.

25. Liu L, Zhang N, Min J, et al. Retrospective analysis on the safety of 5,759 times of bedside hyperthermic intraperitoneal or intra-pleural chemotherapy (HIPEC). Oncotarget 2016;7:21570-8.

26. Yellin A, Simansky DA, Paley M, et al. Hyperthermic pleural perfusion with cisplatin: early clinical experience. Cancer 2001;92:2197-203.

27. de Bree E, van Ruth S, Baas P, et al. Cytoreductive surgery and intraoperative hyperthermic intrathoracic chemotherapy in patients with malignant pleural mesothelioma or pleural metastases of thymoma. Chest 2002;121:480-7.

28. Maury JM, Drevet G, Tronc F, et al. Intra-Thoracic Chemo-Hyperthermia for pleural recurrence of thymomas. J Thorac Dis 2017;9:E1137-9.

29. Rusch VW, Niedzwiecki D, Tao Y, et al. Intrapleural cisplatin and mitomycin for malignant mesothelioma following pleurectomy: pharmacokinetic studies. J Clin Oncol 1992;10:1001-6.

30. Ratto GB, Civalleri D, Esposito M, et al. Pleural space perfusion with cisplatin in the multimodality treatment of malignant mesothelioma: a feasibility and pharmacokinetic study. J Thorac Cardiovasc Surg 1999;117:759-65.

31. Oleson JR, Calderwood SK, Coughlin CT, et al. Biological and clinical aspects of hyperthermia in cancer therapy. Am J Clin Oncol 1988;11:368-80.

32. Jacquet P, Averbach A, Stuart OA, et al. Hyperthermic intraperitoneal doxorubicin: pharmacokinetics, metabolism, and tissue distribution in a rat model. Cancer Chemother Pharmacol 1998;41:147-54.

33. van Ruth $\mathrm{S}$, van Tellingen $\mathrm{O}$, Korse CM, et al. Pharmacokinetics of doxorubicin and cisplatin used in intraoperative hyperthermic intrathoracic chemotherapy after cytoreductive surgery for malignant pleural mesothelioma and pleural thymoma. Anticancer Drugs 2003;14:57-65.

34. Sugarbaker PH, Chang D, Stuart OA. Hyperthermic intraoperative thoracoabdominal chemotherapy.

Gastroenterol Res Pract 2012;2012:623417.

35. Refaely Y, Simansky DA, Paley M, et al. Resection and 


\section{Page 12 of 12}

perfusion thermochemotherapy: a new approach for the treatment of thymic malignancies with pleural spread. Ann Thorac Surg 2001;72:366-70.

36. Ried M, Potzger T, Braune N, et al. Cytoreductive surgery and hyperthermic intrathoracic chemotherapy perfusion for malignant pleural tumours: perioperative management and clinical experience. Eur J Cardiothorac Surg 2013;43:801-7.

37. Ried M, Potzger T, Sziklavari Z, et al. Extended surgical resections of advanced thymoma Masaoka stages III and IVa facilitate outcome. Thorac Cardiovasc Surg 2014;62:161-8.

Cite this article as: Aprile V, Bacchin D, Korasidis S, Ricciardi R, Petrini I, Ambrogi MC, Lucchi M. Hypertermic Intrathoracic Chemotherapy (HITHOC) for thymoma: a narrative review on indications and results. Ann Transl Med 2021;9(11):957. doi: 10.21037/atm-20-6704

\section{Aprile et al. HITHOC after surgery for advanced thymoma}

38. Yellin A, Simansky DA, Ben-Avi R, et al. Resection and heated pleural chemoperfusion in patients with thymic epithelial malignant disease and pleural spread: a single-institution experience. J Thorac Cardiovasc Surg 2013;145:83-7.

39. Yu L, Jing Y, Ma S, et al. Cytoreductive surgery combined with hyperthermic intrapleural chemotherapy to treat thymoma or thymic carcinoma with pleural dissemination. Onco Targets Ther 2013;6:517-21.

40. Detterbeck FC, Zeeshan A. Thymoma: current diagnosis and treatment. Chin Med J (Engl) 2013;126:2186-91. 